\title{
Subtractive hybridization-assisted screening and characterization of genes involved in the rice-Magnaporthe oryzae interaction
}

\author{
Qing-Le Chang ${ }^{1}$, Hai-Jiao Xu', You-Liang Peng ${ }^{1,2}$ and Jun Fan ${ }^{1,3^{*}}$ (D)
}

\begin{abstract}
Transcription profiling assays have revealed substantial changes in gene expression during plant-microbe interactions, but it is often time- and labor-consuming to define the causative roles of the differentially expressed genes that finetune the plant responses to diverse pathogens. We improved the duplex-specific nuclease-mediated transcriptome subtraction method and integrated it with SMART cDNA library construction technology to generate normalized libraries consisting of full-length cDNAs derived from transcripts upregulated in the rice-Magnaporthe oryzae interaction. By adding BP recombination sites to the sequence of primers used for the synthesis of fulllength cDNAs, we were able to transfer the full-length cDNAs of the library to an expression binary vector with CaMV 35 S promoter, which allowed a subsequent screening for candidate genes potentially involved in the disease process by Agrobacterium-mediated transient assay. Results showed that the newly established approach preferentially suppressed the cDNA abundance of most constitutive genes and enriched or normalized that of the upregulated ones. Subsequent screening with transient expression in planta isolated 61 clones, which carry fulllength cDNAs of 32 distinct genes, were capable of causing cell death on Nicotiana benthamiana. When transiently expressed in barley leaf, five of the identified genes were able to induce chlorosis, and additional 11 genes were found to promote disease symptoms caused by infection with the blast pathogen while the others did not enhance the symptoms of pathogen infection. These observations demonstrate that the subtractive hybridizationassisted functional screening is an efficient approach that provides initial leads to the role of candidate genes in the complex process of plant-microbe interactions.
\end{abstract}

Keywords: Duplex-specific nuclease, Subtractive hybridization, Pathogenesis-related genes, Functional screening, Transient expression, Cell death, Chlorosis, Rice blast disease

\section{Background}

Transcriptional reprogramming has a key role in modulating plant responses to biotic and abiotic stresses. Multiple high throughput technologies, including expressed sequence tags analysis (EST), microarray, and transcriptome sequencing, have been used to document the global changes in gene expression during plant-pathogen interactions (Jantasuriyarat et al. 2005; Mosquera et al. 2009; Polesani et al. 2010; Yang et al. 2013; Dong et al. 2015). As a result, these techniques produce a large

\footnotetext{
* Correspondence: jfan@cau.edu.cn

${ }^{1}$ Ministry of Agriculture Key Laboratory for Crop Pest Monitoring and Green Control, China Agricultural University, Beijing 100193, China

${ }^{3}$ Joint Laboratory for International Cooperation in Crop Molecular Breeding, Ministry of Education, China Agricultural University, Beijing 100193, China Full list of author information is available at the end of the article
}

amount of data regarding changes in transcription profiles in response to pathogen infection. However, causative roles of most of these changes in gene expression for disease resistance or susceptibility can hardly be established simply by transcription profiling assays. For instance, it has been shown that transcription factors massively induced in a disease process may enhance resistance against the same pathogen when overexpressed in planta (Chujo et al. 2014; Jimmy and Babu 2015). Likewise, numerous defense-related genes can be upregulated during compatible host-pathogen interactions (Fung et al. 2008; Bagnaresi et al. 2012; Wang et al. 2014). Nevertheless, increasing evidence has shown that plant susceptibility is actively manipulated by pathogens during the infection process. The rice bacterial blight 
pathogen, Xanthomonas oryzae pv. oryzae, is able to secrete transcription activator-like effectors into plant cells to upregulate the transcription of a range of sugar transporter genes and promote the gain of nutrition essential for the successful establishment of pathogen infection (Chen et al. 2010); the overexpression of some pathogenesis-related genes, such as HSC70 and OsWRKY28, has been shown to enhance the development of plant disease-related symptoms (Noël et al. 2007; Chujo et al. 2013). At present, our knowledge on the plant susceptibility genes conditioning the compatible disease process is still limited, and the molecular mechanisms underlying the plant disease susceptibility still remain elusive. Adding to the complexity of the disease-associated transcriptional reprogramming, not all the upregulated genes are directly involved in the disease process: pathogen infections often trigger robust biological crosstalks that lead to transcriptional activation of genes conditioning other biological processes including plant growth and response to abiotic stresses (Berri et al. 2009; Polesani et al. 2010; Wang et al. 2014). Thus, it is of great significance to produce functional information about the commonly hundreds or thousands of genes differentially expressed in the plant-microbe interactions, and to determine the key players mediating diverse disease outcomes.

Suppression subtractive hybridization (SSH) is a PCRbased approach to highlight differentially expressed genes between two populations of transcripts (Diatchenko et al. 1996), and it has been widely used in the study of transcriptional regulation of various biological processes including human disease (Miyasaka et al. 2001) and plant responses to biotic and abiotic stresses (Xiong et al. 2001; Zhang et al. 2002; Thara et al. 2003; Kim et al. 2010; Wang et al. 2012; Kumar et al. 2013). However, the conventional SSH protocol generates short ESTs rather than full-length cDNAs in nearly all cases (Diatchenko et al. 1996; Diatchenko et al. 1999). To enrich full-length cDNAs of differentially expressed genes, the duplex-specific nuclease (DSN), which only cleaves double-strand DNAs, has been used in the subtractive hybridization system to eliminate most of the hybridized sequences. This DSN-mediated transcriptome subtraction (DTS) has been shown successful in isolation of full-length cDNAs of differentially expressed genes, but it still relies on homology searches to predict the gene function (Peng et al. 2008; Dai et al. 2011; Xue et al. 2012). Therefore, a convenient system still awaits to be established to accommodate the phenotype-based screening of copious full-length cDNAs derived from differentially expressed genes during plant-microbe interactions.

In this study, we modified the DTS method to improve the efficiency of subtractive hybridization and integrated the SMART cloning technology and Gateway cloning technology into the newly developed DSN-mediated subtractive hybridization (hereafter DSH). Using the DSH, we were able to construct on a binary expression vector the normalized library consisting of full-length cDNAs of genes upregulated during the early stage of rice blast disease. We subsequently performed an initial functional screening for the library clones capable of inducing cell death by Agrobacterium-mediated transient assays on Nicotiana benthamiana. Out of 6720 individual clones screened, 61 clones were able to induce cell death, among which 32 genes were identified to encode pathogenesis-related proteins (PR) and a range of hypothetical proteins with unknown functions. Transient expression of these 32 candidate genes in barley leaves further revealed that five of them were able to induce leaf chlorosis per se, and that additional 11 genes promoted disease upon infection with the blast fungus. These data illustrate that the DSH is a robust approach for isolation and functional screening of disease-induced full-length cDNAs.

\section{Results \\ Sampling of plant materials for DSH}

To isolate genes upregulated in the biotrophic stage of infection, detached leaves from rice seedlings (Oryza sativa cv LTH) were inoculated with spore suspensions prepared from a compatible strain (P131) of blast fungus Magnaporthe oryzae. At $36 \mathrm{~h}$ post inoculation (hpi), the water-soaking symptom started to appear on inoculation sites (Additional file 1: Figure S1a); the symptom intensified at $48 \mathrm{hpi}$, and fungal hyphae were visible with microscopic observation of tissues stained with trypan blue (Additional file 1: Figure S1a, b); typical sharp-edged lesions developed at $72 \mathrm{hpi}$ along with the formation of conidiophores on the infected tissues (Additional file 1: Figure S1a, b). We thus collected inoculated tissues at 8 , 18, 24, and 36 hpi as samples from the biotrophic stage (Kankanala et al. 2007; Mosquera et al. 2009; Khang et al. 2010) to prepare the tester cDNAs, and samples from 2 hpi were used to prepare the driver cDNAs for the DSH experiment (Diatchenko et al. 1996).

\section{The principle of DSH}

A schematic representation of the DSH method is shown in Fig. 1a. To prepare tester cDNAs, a mixture of mRNAs from above-mentioned samples was reverse transcribed with the oligo attB2-TSpoly $\mathrm{T}_{30}$ in the presence of a template-switching oligo attB1-TSO, generating attB1/attB2 Gateway cloning sites at the $5^{\prime}$ - and $3^{\prime}$ ends of the first-strand tester cDNAs, which allowed cDNAs to be transferred into the expression binary vector for the construction of the library used for functional screening. These first-strand cDNAs were subsequently enriched by PCR amplification with primers of tester-cDNA templateF/tester-cDNA templateR (Fig. 1a) carrying SfiI sites used in the SMART cDNA Library construction technology from Clontech, to allow cloning 


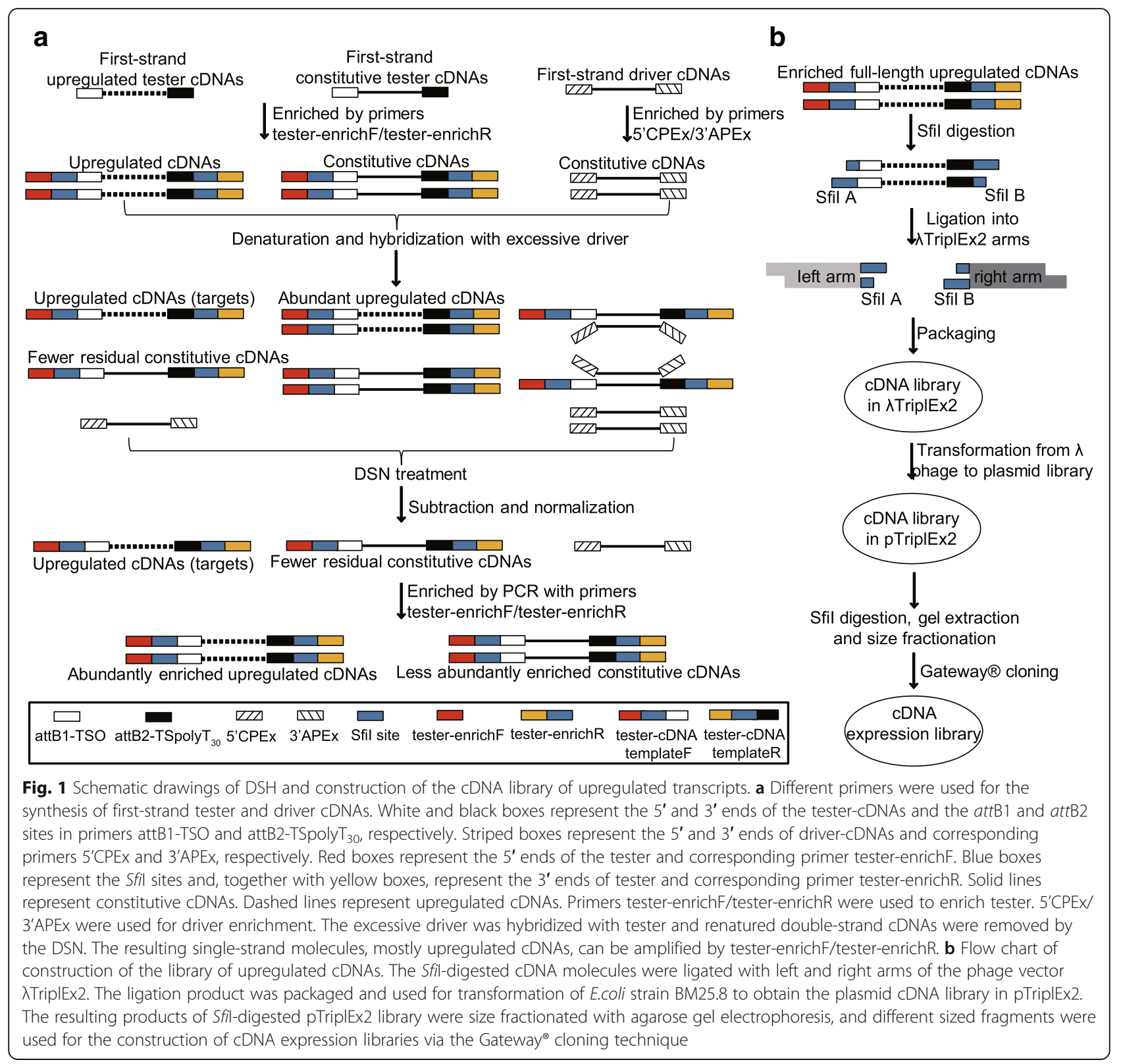

of the normalized cDNAs into the $\lambda$ phage vector during library construction (Fig. 1b). Similarly, the first-strand driver cDNAs were reverse transcribed with primers 5'CPEx-TSO/3'APEx-poly $\mathrm{T}_{30}$, and resultant cDNAs were enriched with $\mathrm{PCR}$ amplification with the primer pair of 5'CPEx/3'APEx.

For DSH hybridization, the tester is mixed with an excessive amount of driver cDNAs and heat-denatured thoroughly prior to renaturation at $68^{\circ} \mathrm{C}$ for $8 \mathrm{~h}$. Based on the second order kinetics of hybridization (Britten and Davidson 1985; Diatchenko et al. 1996), high-abundance cDNAs anneal faster than low-abundance ones, and hence, most of the cDNAs of house-keeping genes in tester anneal faster with excessive driver cDNAs to form double-strand (ds) molecules. By contrast, most of the cDNAs of upregulated genes and some low-abundance constitutive cDNAs may remain as single-strand (ss) DNAs after hybridization. The ds cDNAs formed by renaturation are subsequently cleaved by DSN, but the ss cDNAs will be reserved. As a result, the highly abundant cDNAs are subtracted and cDNAs at various abundance levels in tester are normalized at the same time. The remainder of tester ss cDNAs is selectively amplified by PCR using primers of tester-enrichF/tester-enrichR, which may lead to a relative enrichment of upregulated cDNAs compared with constitutive ones (Fig. 1a). 


\section{The effect of DSH on subtractive hybridization and normalization of CDNAs}

Our initial attempts of DSH using the DTS hybridization parameters rendered strong variation in subtractive hybridization among diverse cDNA molecules. According to the protocol of DTS hybridization, tester and driver cDNAs are mixed with hybridization buffer and denatured at $98^{\circ} \mathrm{C}$ for 2 min to produce ss cDNA molecules (Peng et al. 2008). To test whether this was the optimal condition for thorough melting of cDNAs, we selected two constitutive genes of rice plant (OsActin and $O s C A T-A)$ to investigate the extent of denaturation of the tester and driver cDNAs. Following denaturation, samples were treated with DSN to remove undenatured ds cDNAs, and levels of residual ss cDNAs were assayed with semiquantitative PCR. Results showed that in comparison with the non-DSN treated samples, cDNAs of OsCAT-A, but not OsActin, were dramatically lost in DSN treated samples (Fig. 2a), indicating that OsCAT-A cDNAs were poorly denatured. To circumvent this problem, cDNA samples were denatured without addition of the hybridization buffer, and results showed that DSN treatment had little impact on ss cDNA levels of both OsActin and OsCAT-A genes (Fig. 2b), suggesting that heat denaturation prior to the addition of hybridization buffer is crucial to improve the effect of DSH on cDNA subtraction and normalization.

We selected a number of reference genes, including those constitutively expressed in the blast fungus ( $M O A c-$ tin, EF-1 $\alpha, \beta$-tubulin) and rice plant (OsActin, OsCAT-A, $O s P d x B$ ) (Dong et al. 2015), and those upregulated during disease in the pathogen (MoFLS, $\alpha / \beta$ hydrolase, MoSTL1) (Dong et al. 2015) and rice plant (OsPR10a, OsJAmyb, OsTerpene) (Lee et al. 2001; McGee et al. 2001; Jantasuriyarat et al. 2005), to analyze the effect of DSH by semiquantitative PCR. The cycle numbers showing clear amplification were compared for individual genes between DSH and non-DSH samples. Results showed that the abundance of cDNAs of selected genes varied among samples prepared for DSH (Additional file 2: Figure S2); after DSH treatment, however, amplification of most of the constitutive genes was inhibited more than 5 cycles. Notably, the amplification of the $\beta$-tubulin gene was delayed by approximately 10 cycles, whereas OsCAT$A$ and $O s P d x B$ could not even be detected in the assay. These results indicated that levels of constitutive cDNAs were greatly suppressed by DSH (Fig. 3 and Table 1). In contrast, DSH advanced the amplification of half of the upregulated genes (MoFLS, MoSTL1, and OsTerpene) by nearly 5 cycles, although amplification profiles of $\alpha / \beta$ hydrolase and OsJAmyb changed little, and that of OsPR10a was even slightly suppressed. Comparing the abundance of cDNAs from the upregulated genes in samples with and without DSH treatment, we observed an enrichment of the low-abundance MoSTL1 and OsTerpene, and a reduction of high-abundance OsPR10a cDNAs, which demonstrated a trend of normalization of the cDNAs of upregulated genes (Fig. 3 and Table 1).

\section{Construction of the full-length cDNA library for functional screening}

Conventional SSH procedures use two PCR amplifications to obtain differentially expressed cDNA fragments for subsequent cloning (Diatchenko et al. 1996; Diatchenko et al. 1999; Dai et al. 2007). It is much challenging, however, to proportionally amplify full-length CDNA species with successive PCR reactions, we repeatedly experienced high levels of biased amplification of short cDNA fragments, heavily masking the amplification of target full-length cDNAs. Thus, we amplified the DSN-treated hybridization products with only one round of PCR, and subsequently adopted SMART cDNA Library construction technology (Clontech), in which the resulting amplified fragments were digested with $S f i$ I

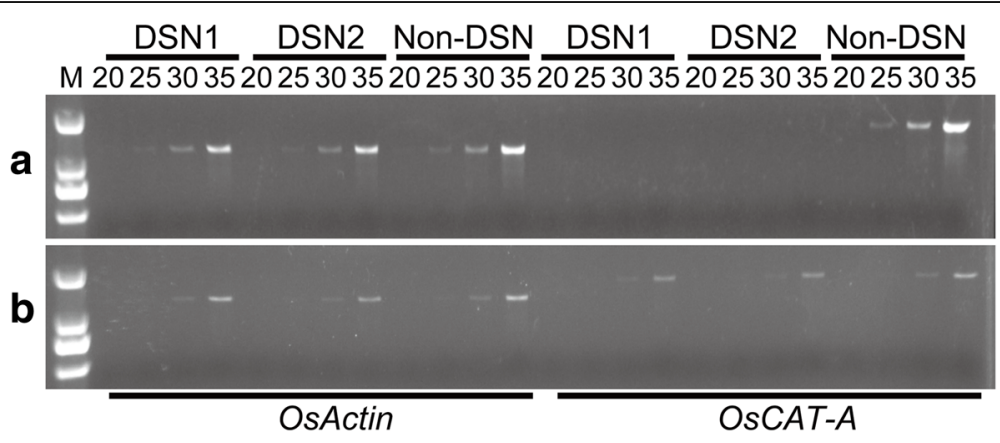

Fig. 2 Hybridization buffer prevented complete denaturation of cDNAs. The driver with hybridization buffer (a) or $10 \mathrm{mM}$ Tris- $\mathrm{HCl}(\mathbf{b})$ were denatured at $98^{\circ} \mathrm{C}$ for $2 \mathrm{~min}$, and then treated with DSN at $68^{\circ} \mathrm{C}$ for $10 \mathrm{~min}$ and subsequently inactivated at $98^{\circ} \mathrm{C}$ for $5 \mathrm{~min}$. Using denatured driver CDNAs as template, genes OsActin and OsCAT-A were amplified by gene-specific primers. Aliquots of PCR reaction mixture were taken at 20, 25,30 , and 35 cycles of amplification and the products were analyzed on $1 \%$ agarose gels as indicated. "DSN1" and "DSN2" represent repeated treatment with DSN, and "Non-DSN" indicates samples without DSN treatment in the reaction mixture. Lane M, DNA ladder (Generay. Code No. 1705G22) 


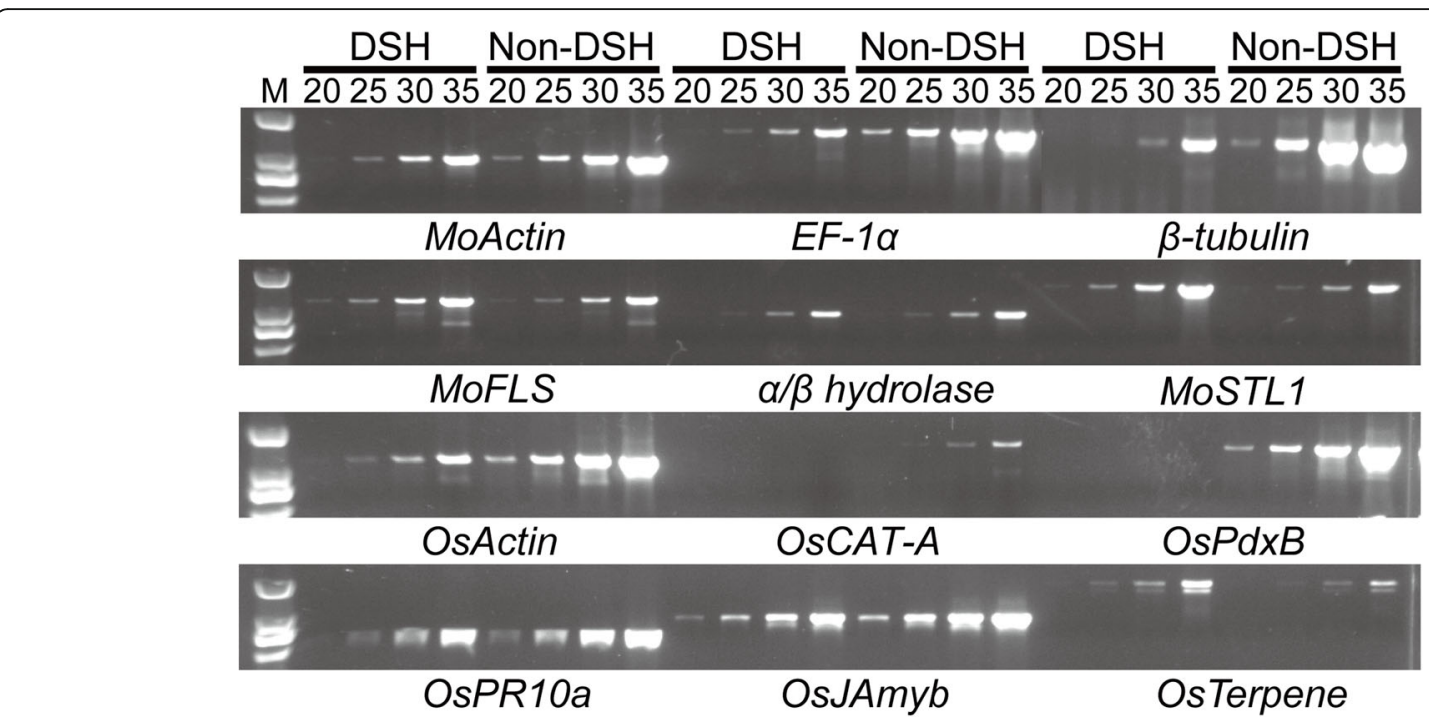

Fig. 3 Constitutive genes were greatly suppressed and upregulated genes were enriched and normalized by DSH. Using DSH and Non-DSH treated products as templates, constitutive genes (MoActin, EF-1a, $\beta$-tubulin, OsActin, OsCAT-A, OsPdxB) and upregulated genes (MoFLS, a/ $\beta$ hydrolase, MOSTL1, OSPR10a, OsJAmyb, OsTerpene) were amplified with gene-specific primers. Aliquots of PCR reaction mixture were taken at 20, 25,30 , and 35 cycles of amplification and the products were analyzed on $1 \%$ agarose gels as indicated. "DSH" represents products treated by DSH, and "Non-DSH" indicates samples without DSH treatment as a control. Lane M, DNA ladder (Generay. Code No. 1705G22)

enzyme and cloned into the $\lambda$ TriplEx2 vector (Clontech) . As a result, a phage library was constructed via phage packaging method, and further converted into a plasmid library by Cre recombinase-mediated site-specific recombination through phage infection of Escherichia coli strain BM25.8 (Fig. 1b). The resulting bacterial colonies were pooled together and plasmids were extracted for construction of the expression libraries. To examine the effect of cDNA normalization, an aliquot of the extracted plasmids was used as the template for PCR assay of the size distribution of cDNA inserts, and the agarose gel electrophoresis revealed a moderate smear of amplified products over $0.5 \mathrm{~kb}$ without the presence of any distinct bands, suggesting that library cDNAs were normalized as expected (Fig. 4a). Next, cDNA inserts were released from the extracted plasmids by Sfil digestion and then size fractionated with agarose gel electrophoresis (Figs. $1 \mathrm{~b}$ and $4 \mathrm{~b}$ ). The cDNA inserts over $0.5 \mathrm{~kb}$ in length were extracted from the gel and introduced into the expression binary vector pCBDEST-transient (Additional file 3: Figure S3) to construct the expression library I through consecutive BP and LR reactions of the Gateway ${ }^{\circ}$ cloning procedure (Fig. 1b). To obtain more full-length cDNAs, a second expression library (II) was constructed with cDNA inserts over $1.5 \mathrm{~kb}$ in length. As a result, bacterial colonies consisting of over $1 \times 10^{6}$ recombinant clones (Additional file 4: Table S1) from both libraries were pooled separately for extraction of plasmids used for transformation of the Agrobacterium strain AGL1.

To test whether the abundance of cDNA species was significantly distorted during the library construction, an aliquot of plasmids from the expression library I was used as templates for amplification of reference genes. Results showed that all the upregulated genes could be amplified in full length, whereas only three constitutive

Table 1 The cycle numbers of clearly visible amplification products of constitutive and upregulated genes

\begin{tabular}{|c|c|c|c|c|c|}
\hline Constitutive gene & $\begin{array}{l}\mathrm{DSH}^{\mathrm{a}} \\
\text { (cycle) }\end{array}$ & $\begin{array}{l}\text { Non-DSH } \\
\text { (cycle) }\end{array}$ & Upregulated gene & $\begin{array}{l}\mathrm{DSH}^{\mathrm{a}} \\
\text { (cycle) }\end{array}$ & $\begin{array}{l}\text { Non-DSH } \\
\text { (cycle) }\end{array}$ \\
\hline MoActin & 25 & 20 & MoFLS & 20 & $25^{d}$ \\
\hline$E F-1 a$ & 25 & 20 & $a / \beta$ hydrolase & 25 & 25 \\
\hline$\beta$-tubulin & 30 & 20 & MOSTL1 & 20 & $25^{d}$ \\
\hline OsActin & 25 & 20 & OsPR10a & 25 & 20 \\
\hline OsCAT-A & $\mu^{c}$ & 30 & OsJAmyb & 20 & 20 \\
\hline$O s P d x B$ & $\mu^{c}$ & 20 & OsTerpene & 25 & $30^{\mathrm{d}}$ \\
\hline
\end{tabular}

${ }^{a} \mathrm{PCR}$ amplification of samples treated by DSH; ${ }^{\mathrm{b}} \mathrm{PCR}$ amplification of samples not treated by $\mathrm{DSH} ;{ }^{\mathrm{c}}$ The genes had no amplified products after DSH treatment; ${ }^{\mathrm{d}}$ These cycle numbers were confirmed because amplification products were clearly visible 


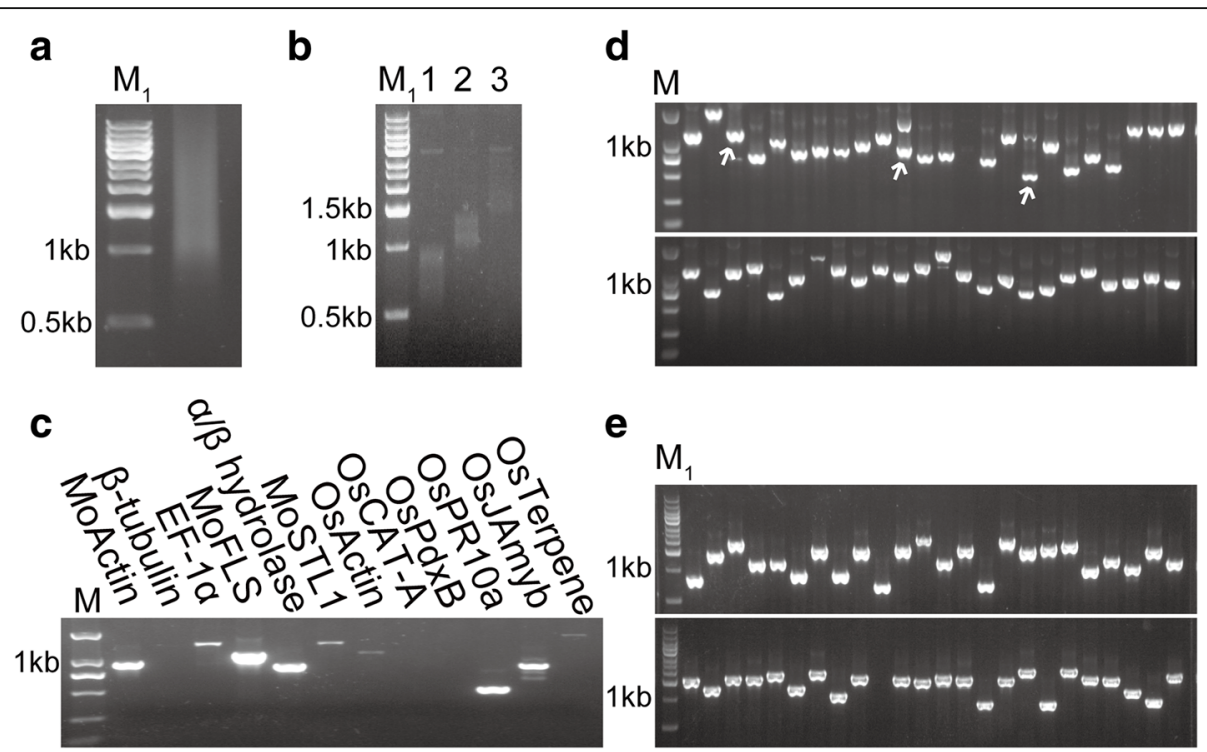

Fig. 4 The PCR assay of the full-length cDNA libraries of upregulated genes. a The PCR amplified inserts from the pTriplEx2 library. Using the library plasmids as template, the insert fragments were amplified by vector-specific primers. b Size fractionation of cDNA inserts. Lanes 1-3, different ranges $(0.5-1 \mathrm{~kb}, 1-1.5 \mathrm{~kb},>1.5 \mathrm{~kb})$ of fractionated cDNA inserts. c Gene-specific analysis. Using plasmids of the expression library I as templates, reference genes were amplified by gene-specific primers. The products were analyzed on $1 \%$ agarose gels as indicated. $\mathbf{d}$ and $\mathbf{e}$ Sizes of the library inserts. Randomly selected 48 colonies from library I (d) and II (e) were used as templates, and vector-specific primers were used for PCR. The arrows indicate the bands of expected size when two distinct bands appeared. Lane M, DNA ladder (Generay. Code No. 1709G22). Lane M, DNA ladder (Generay. Code No. 1705G22)

genes (MoActin, EF-1 $\alpha$, and OsActin) could be detected (Fig. 4c). These results were consistent with the result of the efficiency analysis of DSH (Fig. 3), indicating that the library faithfully retained the cDNA species of DSH products. In addition, we randomly selected 48 bacterial colonies from each of the libraries for PCR amplification of the cDNA inserts, and results showed that the number of clones carrying longer cDNA inserts (over $1 \mathrm{~kb}$ ) in library I was only half of that in library II (22 vs 40) (Fig. 4d, e), indicating that the size fractionation effectively enriched longer cDNAs in library II.

\section{Screening and identification of candidate genes important for the blast disease}

Heterologous expression-assisted gain-of-function analysis provides an effective approach for the identification of candidate genes potentially involved in a biological process under study. Previous studies have shown that phytopathogens are likely to target converged plant components to facilitate disease (Mukhtar et al. 2011; Weßling et al. 2014), and the blast fungus is a notorious pathogen capable of causing lesions during infection. Hence, we chose Agrobacterium-mediated transient expression assay to screen for the clones capable of inducing cell death on $N$. benthamiana. The Agrobacterium strain AGL1 was transformed with the plasmids of the expression library I or II, and resulting single transformants were used to infiltrate plant leaves. From a total of 6720 individual clones screened, 61 clones were found to be able to trigger plant cell death to different extents (Fig. 5a and Table 2).

Sequencing analysis revealed that 56 out of the 61 clones carry cDNAs with intact start and stop codons, and some genes were hit multiple times in the screening-for example, ten clones were found to encode zinc finger protein 1 and four were Myb-related protein 308-indicating that either these genes are overrepresented in the library or the screening is nearly saturated. Collectively, these 61 clones encode 32 proteins with diverse annotated functions (Table 2), among which one hypothetical protein and a polysaccharide deacetylase are from the pathogen, and the rest are all from rice plant. Twelve of the rice proteins were annotated as transcription factors including MYB-related factors, WRKYs, and zinc finger proteins; eleven were proteins with other functions such as chitinase, AT-hook motif nuclearlocalized protein, chloroplastic ribonucleo protein, peptidyl-prolyl cis-trans isomerase (PPIase), CASP-like protein, heat shock cognate protein, serine/arginine-rich splicing factor, pre-mRNA splicing factor, ubiquitin-40S ribosomal protein, and sensitive to proton rhizotoxicity protein; still were seven proteins with unknown functions. To determine whether these genes are also involved in the plant-microbe interaction, the isolated Agrobacterial clones were used to transiently express these genes in barley leaves (Hordeum vulgare cv. E9) and the leaves were 

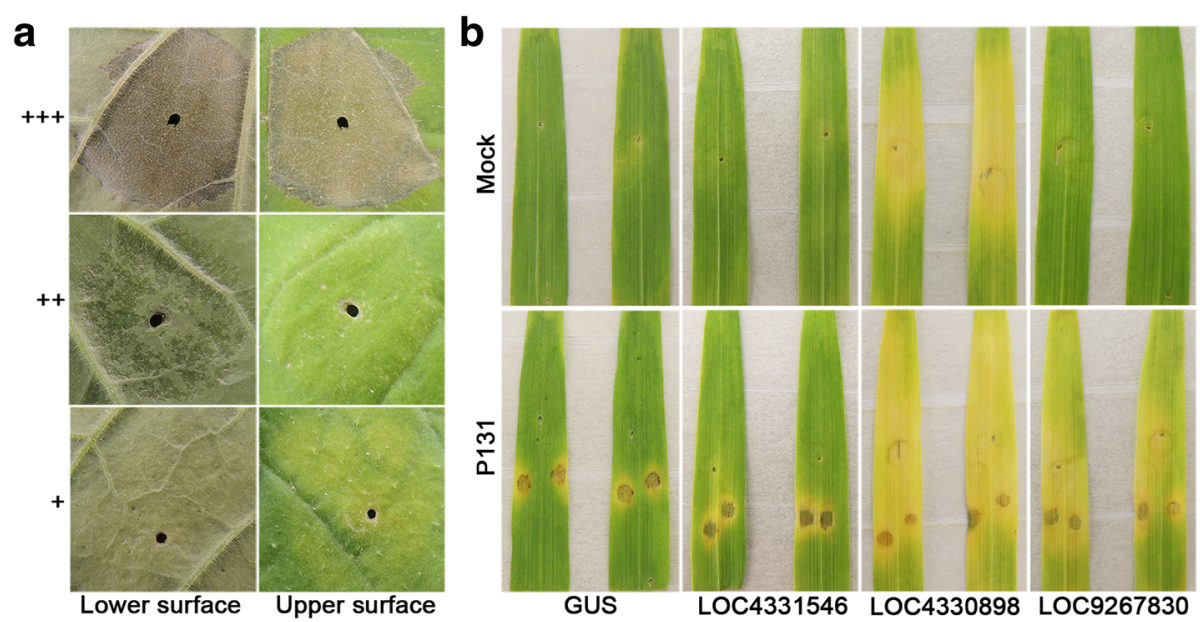

Fig. 5 Transient gene expression assays on N. benthamiana and barley plants. a Cell death was induced by candidate clones on the upper and lower surface of leaves on $\mathrm{N}$. benthamiana plants as indicated. The Agrobacterium suspensions in $10 \mathrm{mM} \mathrm{MgCl} 2\left(\mathrm{OD}_{600}>0.5\right)$ were infiltrated with a needleless syringe into leaves of $\mathrm{N}$. benthamiana plants, and the infiltrated plants were incubated at $24^{\circ} \mathrm{C}$ in a growth room with a 16 -h light/8-h dark cycle. Photos were taken at 5 days after infiltration. $\mathbf{b}$ Chlorosis was induced on barley leaves by transient expression of candidate genes without (Mock) and with (P131) the inoculation of the blast fungus strain P131. The $\beta$-glucuronidase (GUS) and LOC4331546 represent proteins incapable of inducing chlorosis. LOC4330898 and LOC9267830 represent proteins capable of triggering leaf chlorosis without or with subsequent blast fungus inoculation, respectively. Detached barley leaves transiently expressing candidate genes were inoculated with blast fungus strain P131 (5 $\times 10^{5} \mathrm{spores} /$ $\mathrm{mL}$ ) and incubated in a growth chamber at $26^{\circ} \mathrm{C}$ with a photoperiod of $16-\mathrm{h}$ light/8-h darkness. Representative leaves were photographed at $96 \mathrm{~h}$ after inoculation. The experiment was repeated three times and similar results were observed. " +++ " indicates tissue collapse of the Agrobacteriainoculated region; " ++ " and " + " indicate partial or sporadic cell death, respectively, observed on the lower surface of leaves

subsequently challenged with the blast fungus. Results showed that half of these genes were able to promote lesion formation caused by the blast fungus compared with the expression of the gene encoding $\beta$-glucuronidase (GUS) (Fig. 5b, bottom panel and Table 2). In particular, the expression of five candidate proteins alone could trigger leaf chlorosis in the absence of the fungal infection (Fig. 5b, upper panel).

\section{Discussion}

This study streamlined a novel procedure for the identification of genes associated with the process of plant disease. As the PCR-based SSH technique is inefficient for isolation of the full-length cDNAs, we adopted the idea of DTS and made significant changes to improve the efficiency of the DSH and subsequent library construction: (i) Tester and driver are denatured in $10 \mathrm{mM}$ Tris$\mathrm{HCl}$ buffer ( $\mathrm{pH}$ 8.0) instead of the hybridization buffer to promote complete melting of cDNAs (Fig. 2), and protect from damage of DNA by heat treatment as well (Bruskov et al. 2002); (ii) Highly efficient phage cloning was used to construct the library and thereby minimized the undesirable selection for shorter fragments during PCR amplification and plasmid cloning of the full-length cDNAs; (iii) Gateway ${ }^{\circ}$ cloning technology was incorporated to allow cDNA library being transferred conveniently into diverse expression systems.
The efficiency of the DSH method was corroborated by surveying a panel of constitutive and upregulated genes from rice and the blast fungus, and we observed, as expected, the obvious suppression of cDNA abundance of six constitutive genes, and a relative enrichment or normalization of six genes upregulated in the rice-blast fungus interaction (Fig. 3 and Table 1). Moreover, the patterns of cDNA amplification by semiquantitative PCR were similar between DSH product and the plasmids of the expression library (Figs. 3 and 4c), suggesting that the final expression library has a good representation of diverse cDNA species in the DSH product. Nevertheless, not all of the tested reference genes behaved as expected. For instance, the signal of weakly upregulated rice gene OsPGIP1 was lost after DSH treatment (Additional file 2: Figure S2 and Additional file 5: Figure S4), which could be due to that high GC content (70\%) of the cDNA led to insufficient denaturation or over hybridization of the molecule. We also found two constitutive cDNAs from the fungus, such as MGG_01160 and MGG_04467, were recalcitrant to subtraction (Additional file 2: Figure S2 and Additional file 5: Figure S4).

The transition of lifestyle of a hemibiotrophic phytopathogen, such as the blast fungus, from biotroph to necrotroph is presumably associated with necrosis and lesion formation on infected tissues (Kankanala et al. 2007; Horbach and Deising 2013; Jones et al. 2016), but the exact mechanisms underlying the pathogen phase 
Table $\mathbf{2}$ Information of the candidate gene-encoding proteins

\begin{tabular}{|c|c|c|c|c|c|}
\hline Clone No. & Gene & Encoding protein & $\begin{array}{l}\text { Cell } \\
\text { death }^{a}\end{array}$ & $\begin{array}{l}\text { Induced } \\
\text { chlorosis }^{\mathrm{b}}\end{array}$ & Source \\
\hline 2G7, 38F1, 38G4, 65D9 & LOC4324770 & Myb-related protein 308 & +++ & Yes $^{c}$ & Rice \\
\hline 41E7, 47H4, 70G11 & LOC4346246 & Myb-related protein Zm38 & ++ & Yes & Rice \\
\hline $58 \mathrm{~F} 2$ & LOC4330027 & Myb4-like protein & + & Yes & Rice \\
\hline $32 \mathrm{F1}, 33 \mathrm{G} 9$ & LOC9266213 & Transcription factor Myb 8 & ++ & No & Rice \\
\hline $\begin{array}{l}\text { 16C1, 16E6, 16F5, 23B10, } \\
\text { 24G5, 25A9, 32A11, 32G5, } \\
35 \mathrm{~A} 4,49 \mathrm{~A} 2\end{array}$ & LOC4333423 & Zinc finger protein 1 & +++ & Yes & Rice \\
\hline $\begin{array}{l}\text { 19D7, 30A11, 36G8, 38E2, } \\
52 \mathrm{G} 1,55 \mathrm{~A} 12,65 \mathrm{H} 11\end{array}$ & LOC9267830 & Zinc finger protein 2 & ++ & Yes & Rice \\
\hline $30 A 8$ & LOC4330898 & Zinc finger protein 8 & ++ & Yes $^{c}$ & Rice \\
\hline $31 \mathrm{~A} 8$ & LOC4346072 & RanBP2 zinc finger protein & ++ & No & Rice \\
\hline $47 \mathrm{G} 1$ & LOC4335388 & OsWRKY17 & + & No & Rice \\
\hline $3 \mathrm{~A} 2$ & LOC4341678 & WRKY28-like protein & +++ & No & Rice \\
\hline $11 \mathrm{~B} 7$ & LOC4338413 & OsWRKY70 & + & No & Rice \\
\hline $60 G 5$ & LOC107278717 & OsWRKY72 & ++ & Yes & Rice \\
\hline 35E11 & LOC4349267 & Chitinase 8 & +++ & $Y_{e s}^{c}$ & Rice \\
\hline $6 \mathrm{H} 5$ & LOC4331519 & Chitinase 11 & ++ & Yes $^{c}$ & Rice \\
\hline $12 \mathrm{D} 8$ & LOC4346014 & AT-hook motif nuclear-localized protein 10 & ++ & No & Rice \\
\hline $14 \mathrm{E} 3$ & LOC4331447 & $33 \mathrm{kDa}$ ribonucleo protein, chloroplastic & ++ & No & Rice \\
\hline 23B9 & LOC4333394 & Peptidyl-prolyl cis-trans isomerase $\mathrm{E}$ & + & Yes $^{c}$ & Rice \\
\hline $45 F 10$ & LOC4332476 & Serine/arginine-rich splicing factor RS2Z32 & +++ & Yes & Rice \\
\hline $45 \mathrm{G} 11$ & LOC4331546 & Pre-mRNA splicing factor cwf 23 & +++ & No & Rice \\
\hline $52 \mathrm{~F} 8$ & LOC4328486 & CASP-like protein 2 C2 & + & No & Rice \\
\hline $53 \mathrm{H} 9$ & LOC4332413 & Heat shock cognate 70 kDa protein 2 & ++ & Yes & Rice \\
\hline $4 \mathrm{G} 7$ & LOC4326977 & Ubiquitin-40S ribosomal protein S27a-1 & +++ & No & Rice \\
\hline $13 F 5$ & LOC4329736 & Protein sensitive to proton rhizotoxicity 1 & ++ & No & Rice \\
\hline $5 A 6,11 \mathrm{~A} 10,12 \mathrm{C} 4,65 \mathrm{~B} 12$ & LOC4342269 & Uncharacterized protein & +++ & No & Rice \\
\hline $14 \mathrm{~B} 9,14 \mathrm{~F} 1$ & LOC4334216 & Uncharacterized protein & +++ & Yes & Rice \\
\hline $16 \mathrm{D} 8$ & LOC9271812 & Uncharacterized protein & ++ & Yes & Rice \\
\hline $23 B 5$ & LOC4324656 & Uncharacterized protein & + & No & Rice \\
\hline $42 \mathrm{G} 4,52 \mathrm{~F} 10$ & LOC9267428 & Uncharacterized protein & ++ & No & Rice \\
\hline $44 \mathrm{~A} 3$ & LOC4332848 & Uncharacterized protein & + & Yes & Rice \\
\hline $44 \mathrm{~F} 6$ & LOC9268105 & Uncharacterized protein & + & No & Rice \\
\hline $5 \mathrm{~A} 10$ & MGG_08356 & Polysaccharide deacetylase & ++ & No & Blast fungus \\
\hline $4 \mathrm{H} 10,7 \mathrm{~F} 10$ & MGG_10522 & Hypothetical protein & ++ & Yes & Blast fungus \\
\hline
\end{tabular}

${ }^{\mathrm{a}}$ Cell death was observed on $\mathrm{N}$. benthamiana; ${ }^{\mathrm{b}}$ Chlorosis on barley leaves was induced by gene expression with or without subsequent infection by the blast fungus; ${ }^{c}$ Chlorosis could be induced in absence of the fungal infection; " +++ " indicates tissue collapse of the Agrobacteria-inoculated region; " ++ " and " + " indicate partial or sporadic cell death, respectively, observed on the lower surface of leaves

change and plant cell death are poorly understood. Meanwhile, the loss-of-function genetic screening has only uncovered in the plant a limited number of key genes required for disease susceptibility, probably due to the existence of redundancy among signaling or metabolic pathways leading to the disease outcome. Agrobacterium-mediated transient expression in planta has been widely used as a part of the functional analysis of key genes involved in diverse biological processes. By transient gain-of-function screening of the expression library, we have identified 32 unique candidate genes that are able to trigger cell death when overexpressed in $N$. benthamiana plants, implying that the phase change associated plant cell death may be a highly-regulated process. Consistent with this, many of the genes identified by the screening, including those encoding MYB- 
related proteins (Xiong et al. 2001), Zinc finger proteins (Xiong et al. 2001; Li et al. 2014) and WRKYs (Song et al. 2010; Chujo et al. 2013; Chen et al. 2017), have been reported to be upregulated during pathogen infection of the rice plants. For instance, OsWRKY72 is a senescence-associated transcription factor and may mediate the ROS-induced cell death in rice plant (Zhou et al. 2013). Moreover, multiple candidate proteins or their closely related orthologs have been shown implicated in diverse plant-microbe interactions. Rice chitinase 11 is a PR protein strongly induced by pathogen infection, and overexpression of the protein in transgenic rice plants enhances the resistance against sheath blight disease (Grover 2012; Kumar et al. 2018); whereas the PPIases, which mediate protein folding in the endoplasmic reticulum, are targeted by pathogens to subdue plant defenses (Kromina et al. 2008; Fan et al. 2018). In contrast, OsWRKY28 has been identified as a negative regulator of immunity and can enhance susceptibility to blast disease when overexpressed in transgenic plants (Chujo et al. 2013; Chen et al. 2017); likewise, overexpression of the Arabidopsis heat shock cognate 70 (HSC70), sharing over $90 \%$ of sequence identity with the candidate rice heat shock cognate protein 2 found in this study, disables resistance to virulent pathogen strains including Hyaloperonospora parasitica Noco2 and Pseudomonas syringae pv tomato DC3000 (Noël et al. 2007).

Interestingly, except for the leaf chlorosis caused by the expression of the five candidate proteins such as Myb-related protein 308 and Zinc finger protein 8, we did not observe prominent cell death akin to that on $N$. benthamiana following the transient expression of these genes in barley. This may be due to the low efficiency of the transient expression system on the barley plant. Nevertheless, the expression of half of the identified genes in barley indeed promoted the development of blast disease symptom, indicating that they may play important roles in the barley-M. oryzae interaction (Fig. 5b and Table 2). In addition, multiple genes which have not yet been reported as players in the plant-microbe interactions were also picked up by this study from both rice and the blast fungus. Further experiments with rice plant will elucidate the exact roles of these genes in pathogentriggered cell death and plant susceptibility or resistance against the blast disease. The DSH library constructed in this study can also be used to generate stable rice transformants so that lines with aberrant disease phenotypes can be isolated by a direct screening with blast disease. Thus, the DSH assisted screening will provide a versatile and efficient tool to complement loss-of-function screening for the discovery of genes involved in the highly complex biological processes including plant disease susceptibility and potentially many other biotic and abiotic stress responses in the model and non-model crop plants.

\section{Conclusions}

An approach of gain-of-function screening of full-length cDNAs derived from genes upregulated in the rice-Magnaporthe oryzae interaction was established in this study, taking the advantage of an improved method of subtractive hybridization, SMART cDNA library construction, and Gateway cloning technologies. Multiple genes were identified by the transient expression screening of the full-length cDNA library clones that were able to cause cell death, induce leaf chlorosis, or promote blast disease in planta. The newly established approach provides an efficient tool for the identification of genes involved in diverse plant-microbe interactions.

\section{Methods}

\section{Plant materials}

Plants of rice cultivar Oryza sativa cv. LTH were grown at $28{ }^{\circ} \mathrm{C}$ in a greenhouse, and seedlings at five-leaf-stage were used for inoculation with the blast fungus. Plants of barley cultivar Hordeum vulgare cv. E9 and Nicotiana benthamiana were grown at $24^{\circ} \mathrm{C}$ in a growth room with a 16-h light/8-h dark cycle. Five-week-old $N$. benthamiana plants were used for Agrobacteria-mediated transient expression. Barley seedlings at one-leafstage were used for transient gene expression assay and subsequent inoculation with the blast fungus.

\section{Rice blast inoculation}

The rice blast fungus strain P131 was cultured on oatmeal agar at $28^{\circ} \mathrm{C}$ in darkness. Conidia were prepared as described (Peng and Shishiyama 1988). Segments of detached rice leaves were placed into Petri dishes lined with moist filter paper and inoculated with a spore suspension $\left(2 \times 10^{6}\right.$ spores $/ \mathrm{mL}$ in $0.02 \%$ Tween 20$)$ (Jia et al. 2003). The Petri dishes were placed in a moist chamber and kept in the dark at $26^{\circ} \mathrm{C}$ for $24 \mathrm{~h}$, followed with a photoperiod of $16-\mathrm{h}$ light/8-h dark for $72 \mathrm{~h}$. Leaf tissues collected at $2,8,18,24$, and 36 hpi were snap frozen with liquid nitrogen and stored at $-80^{\circ} \mathrm{C}$ until use. For the inoculation of barley leaves, $5 \mu \mathrm{L}$ of spore suspension $\left(5 \times 10^{5}\right.$ spores $/ \mathrm{mL}$ in $0.02 \%$ Tween 20$)$ was applied on each side of the midrib of detached leaf segments and the inoculated leaves were incubated under the same conditions as described above. Disease symptoms were observed at $48 \mathrm{hpi}$.

\section{Agrobacterium tumefaciens infiltration assays}

For transient gene expression on $N$. benthamiana plants, plasmids of the expression library were used to transform the Agrobacterium competent cells. Resulting individual colonies grown on agar plates supplemented with $50 \mu \mathrm{g} / \mathrm{mL}$ kanamycin were picked to inoculate a 96-well plate with $200 \mu \mathrm{L}$ of Luria-Bertani (LB) medium in each well. The inoculated plate was shaken at $28^{\circ} \mathrm{C}, 220 \mathrm{rpm}$ 
for 1 day. Bacterial cells were pelleted by centrifugation at $5000 \mathrm{rpm}$ for $10 \mathrm{~min}$ and resuspended with $10 \mathrm{mM}$ $\mathrm{MgCl}_{2}$. The bacterial suspensions were adjusted to $\mathrm{OD}_{600}>0.5$ and infiltrated with a $1 \mathrm{~mL}$ needleless syringe into leaves of $N$. benthamiana plants. The cell death phenotypes were observed at $48 \mathrm{hpi}$. For transient expression of candidate proteins on barley plants, Agrobacteria transformed with the vector carrying candidate genes were grown overnight in LB medium supplemented with $50 \mu \mathrm{g} / \mathrm{mL}$ kanamycin. The bacteria were collected by centrifugation and resulting pellets were resuspended with the infiltration buffer containing $10 \mathrm{mM}$ $\mathrm{MgCl}_{2}, 5 \mathrm{mM}$ Mes, $400 \mu \mathrm{M}$ acetosyringone, and $0.01 \%$ silwet $\mathrm{L}-77$ to an $\mathrm{OD}_{600}$ of 0.5 . The bacterial suspensions were infiltrated with a $1 \mathrm{~mL}$ needleless syringe into the abaxial side of the barley leaves. The infiltrated plants were incubated in a plastic box under $100 \%$ relative humidity for $24 \mathrm{~h}$ and then transferred into a growth room with a photoperiod of 16-h light/8-h dark for $24 \mathrm{~h}$. Next, the inoculated barley leaves were used for infection with the blast fungus.

\section{Extraction of mRNA}

Total RNAs were isolated by using Trizol Reagent (Generay, Shanghai) following manufacturer's instruction. Aliquots of total RNAs from 8, 18, 24, and $36 \mathrm{hpi}$ samples were mixed as tester-RNAs and total RNAs of 2 hpi sample as driver-RNAs. An amount of $240 \mu \mathrm{g}$ of each tester and driver RNAs was taken for extraction of mRNAs using PolyATtract ${ }^{\circ}$ mRNA Isolation Systems (Promega, Cat. No. Z5310) based on manufacturer's instruction, and the resultant mRNAs were used for first-strand cDNA synthesis.

\section{Oligonucleotides and plasmids}

Oligonucleotides and plasmids used in this study were listed in Additional file 6: Table S2 and Additional file 7: Table S3, respectively.

\section{First-strand CDNA synthesis}

The template switching primers attB1-TSO and 5'CPExTSO were designed according to the SMART technique (Pinto and Lindblad 2010) and modified by C3-spacer at 3 '-ends. For the synthesis of first-strand tester-cDNAs, $50 \mathrm{ng}$ of tester-mRNAs was mixed with $0.5 \mu \mathrm{L}$ of attB2TSpoly $_{30}(10 \mu \mathrm{M})$ and $1 \mu \mathrm{L}$ of dNTPs $(10 \mathrm{mM})$ in a total volume of $3.5 \mu \mathrm{L}$. The mixture was heated at $65^{\circ} \mathrm{C}$ for $5 \mathrm{~min}$ and decreased to $50^{\circ} \mathrm{C}$ immediately followed by addition of $2 \mu \mathrm{L}$ of $5 \times$ first-strand buffer (Invitrogen), $1 \mu \mathrm{L}$ of DTT $(100 \mathrm{mM}), 1.2 \mu \mathrm{L}$ of Betaine $(5 \mathrm{M}), 2.5 \mu \mathrm{L}$ of $\mathrm{MgCl}_{2} /$ Trehalose $(12 \mathrm{mM} / 1.2 \mathrm{M}), 0.25 \mu \mathrm{L}$ of RNase Inhibitor (TaKaRa) and $0.4 \mu \mathrm{L}$ of SuperScript III (Invitrogen). The mixture was incubated at $50^{\circ} \mathrm{C}$ for $1.5 \mathrm{~h}$ and then maintained at $48^{\circ} \mathrm{C}$ followed by adding $2 \mu \mathrm{L}$ of $5 \times$ first-strand buffer, $1 \mu \mathrm{L}$ of DTT $(100 \mathrm{mM}), 0.6 \mu \mathrm{L}$ of $\mathrm{MgCl}_{2}(50 \mathrm{mM}), 0.6 \mu \mathrm{L}$ of $\mathrm{MnCl}_{2}(100 \mathrm{mM}), 4 \mu \mathrm{L}$ of attB1-TSO $(10 \mu \mathrm{M}), 0.25 \mu \mathrm{L}$ of RNase Inhibitor, $0.4 \mu \mathrm{L}$ of SuperScript III and $1.15 \mu \mathrm{L}$ of RNase free $\mathrm{H}_{2} \mathrm{O}$. The final mixture was incubated at $48{ }^{\circ} \mathrm{C}$ for $1.5 \mathrm{~h}$ and subsequently inactivated at $70^{\circ} \mathrm{C}$ for $15 \mathrm{~min}$. For the synthesis of first-strand driver-cDNAs, the reaction conditions were the same as the above, except that primers attB2$\mathrm{TSpolyT}_{30} /$ attB1-TSO were replaced by 3'APEx-polyT ${ }_{30} /$ 5'CPEx-TSO, respectively.

\section{Enrichment of tester and driver CDNAs}

An amount of $1 \mu \mathrm{L}$ of $1 / 20$ diluted first-strand testercDNAs was added into $20 \mu \mathrm{L}$ of PCR mixture containing $0.5 \mu \mathrm{M}$ of primers tester-cDNA templateF/tester-cDNA templateR. Other PCR components were added following the user manual of $\mathrm{Q} 5^{\circ}$ High-Fidelity DNA Polymerases (GC enhancer, NEB). The PCR program was: $98^{\circ} \mathrm{C}$ for $30 \mathrm{~s} ; 10$ cycles of $98^{\circ} \mathrm{C}$ for $10 \mathrm{~s}, 68^{\circ} \mathrm{C}$ for $20 \mathrm{~s}$ and $72{ }^{\circ} \mathrm{C}$ for $2 \min 30 \mathrm{~s} ; 72^{\circ} \mathrm{C}$ for $2 \mathrm{~min}$. Next, $1 \mu \mathrm{L}$ of $1 / 10$ diluted resulting products was used as template, and $5 \mu \mathrm{M}$ tester-enrichF/tester-enrichR primers were used to enrich tester by 19 -cycle of amplification according to Q5 manufacturer's instruction. To enrich the driver, $1 \mu \mathrm{L}$ of $1 / 20$ diluted first-strand driver-cDNAs was added into $20 \mu \mathrm{L}$ of PCR mixture containing $0.5 \mu \mathrm{M}$ of primers 5'CPEx/3'APEx for 21-cycle of PCR amplification. Other conditions were the same as those of tester enrichment. The tester and driver products were purified by PCR Purification Kit (Generay, GK2501).

\section{DSN-mediated subtractive hybridization (DSH)}

With modification of previously reported DTS method (Peng et al. 2008), a volume of $4.3 \mu \mathrm{L}$ of mixture containing $100 \mathrm{ng}$ of enriched tester and $500 \mathrm{ng}$ of enriched driver was mixed with $0.8 \mu \mathrm{L}$ of Tris- $\mathrm{HCl}(\mathrm{pH} 8.0,50 \mathrm{mM})$ and denatured at $98{ }^{\circ} \mathrm{C}$ for $2 \mathrm{~min}$ immediately followed by addition of $1.5 \mu \mathrm{L}$ of $4 \times$ HEPES hybridization buffer (200 mM HEPES pH 7.5, $2 \mathrm{M} \mathrm{NaCl}, 0.8 \mathrm{M}$ EDTA $\mathrm{pH} 8.0$ ), and incubated at $68{ }^{\circ} \mathrm{C}$ for $8 \mathrm{~h}$. After that, the preheated buffer containing $1 \mu \mathrm{L}$ of $10 \times \mathrm{DSN}$ buffer (Evrogen, Cat. No. EA003) and $2.5 \mu \mathrm{L}$ deionized $\mathrm{H}_{2} \mathrm{O}$ was added to the reaction mixture. Immediately, $0.25 \mathrm{U}$ of DSN enzyme (Evrogen, Cat. No. EA003) was added and incubated for $10 \mathrm{~min}$ at $68^{\circ} \mathrm{C}$, and subsequently inactivated at $98^{\circ} \mathrm{C}$ for $5 \mathrm{~min}$.

To enrich the subtracted and normalized DSH products, $1 \mu \mathrm{L}$ of $1 / 10$ diluted hybridized products was used as template for a 20-cycle PCR amplification with primers tester-enrichF/tester-enrichR under the same conditions as that used for the enrichment of tester.

\section{Construction of phage and expression libraries}

The enriched DSH product was purified using PCR Purification Kit (Generay, GK2501) and precipitated via 
ethanol precipitation method. A total $100 \mu \mathrm{L}$ of the mixture of SfiI-digestion containing $1.5 \mu \mathrm{g}$ of purified DSH product, $10 \mu \mathrm{L}$ of $10 \times S f i$ buffer, $1 \mu \mathrm{L}$ of $100 \times \mathrm{BSA}$ (SMART $^{\mathrm{TN}}$ cDNA library construction kit, Clontech), $10 \mu \mathrm{L}$ of $S f i \mathrm{I}\left(20\right.$ units $/ \mu \mathrm{L}$ ) and $65 \mu \mathrm{L}$ of deionized $\mathrm{H}_{2} \mathrm{O}$ was incubated at $50{ }^{\circ} \mathrm{C}$ for $2 \mathrm{~h}$ and then purified as same as the above treatment of enriched DSH product. After that, a mixture of ligation reaction containing $50 \mathrm{ng}$ of SfiI-digested products, $500 \mathrm{ng}$ of $\lambda$ TriplEx 2 vector, $0.5 \mu \mathrm{L}$ of $10 \times$ DNA ligation buffer, $0.5 \mu \mathrm{L}$ of ATP $(10 \mathrm{mM})$, $0.5 \mu \mathrm{L}$ of T4 DNA Ligase (400 units $/ \mu \mathrm{L}$ ) and $2 \mu \mathrm{L}$ of deionized $\mathrm{H}_{2} \mathrm{O}$ in a total volume of $5 \mu \mathrm{L}$ followed by incubating overnight at $16^{\circ} \mathrm{C}$.

Following the user manuals of MaxPlax ${ }^{\mathrm{Tx}}$ Lambda Packaging Extracts (Epicentre, Cat. No. MP5110) and SMART $^{\mathrm{ma}}$ cDNA library construction kit (Clontech, Cat. No. 634901), the ligated products were packaged with the packaging extracts and co-cultured with E. coli strain BM25.8. The conversion of a $\lambda$ TriplEx 2 clone to a pTriplEx2 plasmid was achieved by Cre recombinasemediated site-specific recombination in BM25.8. Then, the plasmids were extracted from the bacteria and digested with the SfiI enzyme. The resulting products were resolved with agarose gel electrophoresis, and inserts of desired sizes were recovered from the gel and purified with Agarose Gel Extraction Kit (Generay, GK2043). The fractionated inserts were recombined with pDONR207 by BP Clonase (Invitrogen, Cat. No. 11789013), and the reaction product was used to transform DH5 $\alpha$ competent cells to make the entry library. Plasmids of the resulting library were extracted and used for LR reaction (Invitrogen, Cat. No. 11791-019) to introduce the inserts into the modified binary vector pCBDEST-transient (Additional file 3: Figure S3) to construct the expression library. The resulting reaction product was used to transform the DH5 $\alpha$ strain and colonies grown on LB plates supplemented with $50 \mu \mathrm{g} / \mathrm{mL}$ kanamycin were collected to extract plasmids used for transformation of the Agrobacterium strain AGL1 by electroporation. Individual colonies grown on the selective plates with $50 \mu \mathrm{g} / \mathrm{mL}$ kanamycin were picked for the phenotypic screening of the target clones.

\section{Semiquantitative PCR assay of the abundance of CDNAs}

For semiquantitative PCR, $1 \mu \mathrm{L}$ of $1 / 10$ diluted DSH product was mixed with $25 \mu \mathrm{L}$ of $2 \times$ PCR Mix (Tsingke, TSE004), $4 \mu \mathrm{L}$ of $5 \mu \mathrm{M}$ gene-specific primers and $20 \mu \mathrm{L}$ deionized $\mathrm{H}_{2} \mathrm{O}$ in a total volume of $50 \mu \mathrm{L}$. PCR was performed with the following parameters: $94{ }^{\circ} \mathrm{C}$ for $3 \mathrm{~min}$; 35 cycles of $94{ }^{\circ} \mathrm{C}$ for $30 \mathrm{~s}, 60^{\circ} \mathrm{C}$ for $25 \mathrm{~s}$ and $72{ }^{\circ} \mathrm{C}$ for 1 min $50 \mathrm{~s}$; and a final extension at $72{ }^{\circ} \mathrm{C}$ for $5 \mathrm{~min} .7 \mu \mathrm{L}$ of the samples were taken after $20,25,30$ and 35 cycles of PCR amplification and the products were analyzed on $1 \%$ agarose gels.

\section{Size distribution of CDNAs}

To determine the size distribution of inserts of the library, $10 \mathrm{ng}$ of the library plasmids was taken as template and primers pTriplEx2-seqF/seqR (SMART ${ }^{\mathrm{mm}}$ cDNA library construction kit, Clontech) were used for PCR under the same program as that of the semiquantitative PCR, except that the time for extension was 3 min. The PCR products were analyzed on $1 \%$ agarose gel. For size detection of the inserts of entry clones, colonies were randomly selected as templates and primers pDONRF/pDONRR were used in the same PCR system.

\section{Trypan blue staining}

According to Koch and Slusarenko (Koch and Slusarenko 1990), the infected rice leaf samples were submerged in staining mixture $(10 \mathrm{~mL}$ of lactic acid, $10 \mathrm{~mL}$ of glycerol, $10 \mathrm{~mL}$ of water saturated phenol, $10 \mathrm{mg}$ of trypan blue, dissolved in $10 \mathrm{~mL}$ of distilled water) and boiled for approximately $3 \mathrm{~min}$. Then, the samples were destained in chloral hydrate $(5 \mathrm{~g} / 2 \mathrm{~mL})$ for observation by microscopy.

\section{Additional files}

Additional file 1: Figure S1. Sampling of plant materials for DSH and histological observation of samples collected at different time points. a Detached rice leaves were inoculated with blast fungus strain P131 $\left(2 \times 10^{6}\right.$ spores $/ \mathrm{mL}$ ) and incubated in a growth chamber at $26^{\circ} \mathrm{C}$ with a photoperiod of 16-h light/8-h darkness. Samples were collected at photographed at indicated time points. b The trypan blue staining (Koch and Slusarenko 1990) was performed at 36, 48 and $72 \mathrm{hpi}$ and the stained samples were used for microscopic observation of infection structures of the pathogen. Hyphae (hy) and conidiophore (cp) are indicated. Bars = $20 \mu \mathrm{m}$. (TIF $8338 \mathrm{~kb}$ )

Additional file 2: Figure S2. Analysis of the relative abundance of constitutive and upregulated genes in tester and driver cDNAs. Genes were amplified with gene-specific primers using enriched tester and driver, synthesized tester and driver CDNAs as templates. Aliquots of PCR reaction mixture were taken at 20,25,30, and 35 cycles of amplification and the products were analyzed on $1 \%$ agarose gels as indicated. Constitutive genes are MoActin, EF-1a, $\beta$-tubulin, MGG_01160, MGG_04467, OsActin, OsCAT-A, and OsPdXB and upregulated genes are MoFLS, a/B hydrolase, MOSTL1, OSPR10a, OsJAmyb, OsTerpene, and OsPGIP1. "tester1" and "tester2" represent repeated PCR amplifications using enriched tester as template. Lane M, DNA ladder (Generay. Code No. 1705G22). (TIF 8302 kb)

Additional file 3: Figure S3. Schematic diagram of the pCBDESTtransient vector. attR1 and attR2, Gateway ${ }^{\otimes}$ cloning sites; $c c d B$, Coupled cell division B; LB and RB, Left and right border of T-DNA insert; RK2-oriV, Replication origin oriV from RK2 plasmid; RK2-TrfA, TrfA gene from RK2 plasmid; NPTIII, Aminoglycoside 3'-phosphotransferase gene. (TIF 9770 kb)

Additional file 4: Table S1. The storage capacity of the corresponding library in this study. (DOCX $16 \mathrm{~kb}$ )

Additional file 5: Figure S4. Genes unfit for DSH. No subtractive effects were observed for constitutive genes MGG_01160 and MGG_04467, and CDNAs of the upregulated gene OsPGIP1 were lost after DSH treatment. Gene-specific primers were used for PCR analysis of DSH and Non-DSH treated samples. Aliquots of PCR reaction mixture were taken at 20, 25, 30 , and 35 cycles of amplification and the products were analyzed on $1 \%$ agarose gels as indicated. Lane M, DNA ladder (Generay. Code No. 1705G22). (TIF 7701 kb) 
Additional file 6: Table S2. Oligonucleotides used in this study. (DOCX $18 \mathrm{~kb}$ )

Additional file 7: Table S3. Plasmids used in this study. (DOCX $16 \mathrm{~kb}$ )

\section{Abbreviations}

ds: Double-strand; DSH: DSN-mediated subtractive hybridization; DSN: Duplex-specific nuclease; DTS: DSN-mediated transcriptome subtraction; EST: Expressed sequence tags; hpi: Hours post inoculation; HSC70: Heat shock cognate 70; LB: Luria-Bertani medium.; PR: Pathogenesisrelated proteins; ss: Single-strand; SSH: Suppression subtractive hybridization

\section{Acknowledgements}

We thank members of the Fan lab for technical advice and assistance in the project, and the anonymous reviewers for critical review of the manuscript.

\section{Authors' contributions}

JF conceived and designed the research. Q-LC performed the experiment, and $\mathrm{H}$-JX participated in the barley inoculation experiment. Q-LC, H-JX and JF checked all the data. Q-LC, JF, and Y-LP wrote the manuscript. All authors read and approved the final manuscript.

\section{Funding}

This project is partially supported by the Specialized Research Fund for the Doctoral Program of Higher Education of China (Grant No. 20130008110005).

\section{Availability of data and materials}

All data generated or analyzed during this study are included in this published article and its supplementary information files.

\section{Ethics approval and consent to participate}

Not applicable.

\section{Consent for publication}

Not applicable.

\section{Competing interests}

The authors declare that they have no competing interests.

\section{Author details}

${ }^{1}$ Ministry of Agriculture Key Laboratory for Crop Pest Monitoring and Green Control, China Agricultural University, Beijing 100193, China. ${ }^{2}$ State Key Laboratory of Agrobiotechnology, China Agricultural University, Beijing 100193, China. ${ }^{3}$ Joint Laboratory for International Cooperation in Crop Molecular Breeding, Ministry of Education, China Agricultural University, Beijing 100193, China.

Received: 25 March 2019 Accepted: 15 May 2019

Published online: 10 June 2019

\section{References}

Bagnaresi P, Biselli C, Orrù L, Urso S, Crispino L, Abbruscato P, et al. Comparative transcriptome profiling of the early response to Magnaporthe oryzae in durable resistant vs susceptible rice (Oryza sativa L.) genotypes. PLoS One. 2012;7:e51609.

Berri S, Abbruscato P, Faivre-Rampant O, Brasileiro AC, Fumasoni I, Satoh K, et al. Characterization of WRKY co-regulatory networks in rice and Arabidopsis. BMC Plant Biol. 2009;9:120-41.

Britten R, Davidson E. Hybridization strategy. In: Hames B, Higgins S, editors. Nucleic acid hybridization: a practical approach. Oxford: IRL Press; 1985. p. 3-15.

Bruskov VI, Malakhova LV, Masalimov ZK, Chernikov AV. Heat-induced formation of reactive oxygen species and 8-oxoguanine, a biomarker of damage to DNA. Nucleic Acids Res. 2002:30:1354-63.

Chen F, Hu Y, Vannozzi A, Wu K, Cai H, Qin Y, et al. The WRKY transcription factor family in model plants and crops. Crit Rev Plant Sci. 2017;36:311-35.

Chen LQ, Hou BH, Lalonde S, Takanaga H, Hartung ML, Qu XQ, et al. Sugar transporters for intercellular exchange and nutrition of pathogens. Nature. 2010;468:527-32
Chujo T, Miyamoto K, Ogawa S, Masuda Y, Shimizu T, Kishi-Kaboshi M, et al. Overexpression of phosphomimic mutated OsWRKY53 leads to enhanced blast resistance in rice. PLoS One. 2014;9:e98737.

Chujo T, Miyamoto K, Shimogawa T, Shimizu T, Otake Y, Yokotani N, et al. OsWRKY28, a PAMP-responsive transrepressor, negatively regulates innate immune responses in rice against rice blast fungus. Plant Mol Biol. 2013;82: 23-37.

Dai Z, Li R, Dai L, Yang J, Chen S, Zeng Q, et al. Determination in oocytes of the reproductive modes for the brine shrimp Artemia parthenogenetica. Biosci Rep. 2011:31:17-30.

Dai Z, Zhu X, Chen Q, Yang W. PCR-suppression effect: kinetic analysis and application to representative or long-molecule biased PCR-based amplification of complex samples. J Biotechnol. 2007;128:435-43.

Diatchenko L, Lau Y, Campbell AP, Chenchik A, Moqadam F, Huang B, et al. Suppression subtractive hybridization: a method for generating differentially regulated or tissue-specific cDNA probes and libraries. Proc Natl Acad Sci U S A. 1996:93:6025-30.

Diatchenko L, Lukyanov S, Lau YC, Siebert PD. Suppression subtractive hybridization: a versatile method for identifying differentially expressed genes. Methods Enzymol. 1999:303:349-80.

Dong Y, Li Y, Zhao M, Jing M, Liu X, Liu M, et al. Global genome and transcriptome analyses of Magnaporthe oryzae epidemic isolate 98-06 uncover novel effectors and pathogenicity-related genes, revealing gene gain and lose dynamics in genome evolution. PLoS Pathog. 2015;11:e1004801.

Fan G, Yang Y, Li T, Lu W, Du Y, Qiang X, et al. A Phytophthora capsici RXLR effector targets and inhibits a plant PPlase to suppress endoplasmic reticulum-mediated immunity. Mol Plant. 2018;11:1067-83.

Fung RW, Gonzalo M, Fekete C, Kovacs LG, He Y, Marsh E, et al. Powdery mildew induces defense-oriented reprogramming of the transcriptome in a susceptible but not in a resistant grapevine. Plant Physiol. 2008;146:236-49.

Grover A. Plant chitinases: genetic diversity and physiological roles. Crit Rev Plant Sci. 2012;31:57-73.

Horbach R, Deising HB. The biotrophy-necrotrophy switch in fungal pathogenesis. In: Kempken F, editor. Agricultural applications. Springer Berlin; 2013. p. 343-60.

Jantasuriyarat C, Gowda M, Haller K, Hatfield J, Lu G, Stahlberg E, et al. Large-scale identification of expressed sequence tags involved in rice and rice blast fungus interaction. Plant Physiol. 2005;138:105-15.

Jia Y, Valent B, Lee F. Determination of host responses to Magnaporthe grisea on detached rice leaves using a spot inoculation method. Plant Dis. 2003;87: 129-33.

Jimmy JL, Babu S. Role of OsWRKY transcription factors in rice disease resistance. Trop Plant Pathol. 2015:40:355-61.

Jones K, Kim DW, Park JS, Khang CH. Live-cell fluorescence imaging to investigate the dynamics of plant cell death during infection by the rice blast fungus Magnaporthe oryzae. BMC Plant Biol. 2016;16:69-76.

Kankanala P, Czymmek K, Valent B. Roles for rice membrane dynamics and plasmodesmata during biotrophic invasion by the blast fungus. Plant Cell. 2007;19:706-24.

Khang CH, Berruyer R, Giraldo MC, Kankanala P, Park S, Czymmek K, et al. Translocation of Magnaporthe oryzae effectors into rice cells and their subsequent cell-to-cell movement. Plant Cell. 2010;22:1388-403.

Kim S, Park J, Park S, Mitchell TK, Lee Y. Identification and analysis of in planta expressed genes of Magnaporthe oryzae. BMC Genomics. 2010;11:104-17.

Koch E, Slusarenko A. Arabidopsis is susceptible to infection by a downy mildew fungus. Plant Cell. 1990;2:437-45.

Kromina KA, Ignatov AN, Abdeeva IA. Role of peptidyl-prolyl-cis/trans-isomerases in pathologic processes. Biochem (Moscow) Suppl Ser A Membr Cell Biol. 2008:2:195-202.

Kumar M, Brar A, Yadav M, Chawade A, Vivekanand V, Pareek N. Chitinases_-potential candidates for enhanced plant resistance towards fungal pathogens. Agriculture. 2018;8:88-99.

Kumar S, Anandhan S, Dhivya S, Zakwan A, Sathishkumar R. Isolation and characterization of cold inducible genes in carrot by suppression subtractive hybridization. Biol Plant. 2013;57:97-104.

Lee M, Qi M, Yang Y. A novel jasmonic acid-inducible rice myb gene associates with fungal infection and host cell death. Mol Plant-Microbe Interact. 2001; 14:527-35.

Li WT, Chen WL, Yang C, Wang J, Yang L, He M, et al. Identification and network construction of zinc finger protein (ZFP) genes involved in the riceMagnaporthe oryza interaction. Plant Omics. 2014;7:540-8. 
McGee JD, Hamer JE, Hodges TK. Characterization of a PR-10 pathogenesisrelated gene family induced in rice during infection with Magnaporthe grisea. Mol Plant-Microbe Interact. 2001;14:877-86.

Miyasaka Y, Enomoto N, Nagayama K, Izumi N, Marumo F, Watanabe M, et al. Analysis of differentially expressed genes in human hepatocellular carcinoma using suppression subtractive hybridization. Br J Cancer. 2001;85:228-34.

Mosquera G, Giraldo MC, Khang CH, Coughlan S, Valent B. Interaction transcriptome analysis identifies Magnaporthe oryzae BAS1-4 as biotrophyassociated secreted proteins in rice blast disease. Plant Cell. 2009;21:1273-90.

Mukhtar MS, Carvunis A, Dreze M, Epple P, Steinbrenner J, Moore J, et al. Independently evolved virulence effectors converge onto hubs in a plant immune system network. Science. 2011;333:596-601.

Noël LD, Cagna G, Stuttmann J, Wirthmüller L, Betsuyaku S, Witte CP, et al. Interaction between SGT1 and cytosolic/nuclear HSC70 chaperones regulates Arabidopsis immune responses. Plant Cell. 2007:19:4061-76.

Peng R, Xiong A, Xue Y, Li X, Liu J, Cai B, et al. Kamchatka crab duplex-specific nuclease-mediated transcriptome subtraction method for identifying long cDNAs of differentially expressed genes. Anal Biochem. 2008;372:148-55.

Peng YL, Shishiyama J. Temporal sequence of cytological events in rice leaves infected with Pyricularia oryzae. Can J Bot. 1988;66:730-5.

Pinto FL, Lindblad P. A guide for in-house design of template-switch-based $5^{\prime}$ rapid amplification of cDNA ends systems. Anal Biochem. 2010;397:227-32.

Polesani M, Bortesi L, Ferrarini A, Zamboni A, Fasoli M, Zadra C, et al. General and species-specific transcriptional responses to downy mildew infection in a susceptible (Vitis vinifera) and a resistant (V. riparia) grapevine species. BMC Genomics. 2010:11:117-32.

Song Y, Ai C, Jing S, Yu D. Research progress on functional analysis of rice WRKY genes. Rice Sci. 2010;17:60-72.

Thara VK, Fellers JP, Zhou J. In planta induced genes of Puccinia triticina. Mol Plant Pathol. 2003:4:51-6.

Wang X, Chen J, Wang B, Liu L, Jiang H, Tang D, et al. Characterization by suppression subtractive hybridization of transcripts that are differentially expressed in leaves of anthracnose-resistant ramie cultivar. Plant Mol Biol Rep. 2012;30:547-55.

Wang Y, Kwon SJ, Wu J, Choi J, Lee Y, Agrawal GK, et al. Transcriptome analysis of early responsive genes in rice during Magnaporthe oryzae infection. Plant Pathol J. 2014:30:343-54.

Weßling R, Epple P, Altmann S, He Y, Yang L, Henz SR, et al. Convergent targeting of a common host protein-network by pathogen effectors from three kingdoms of life. Cell Host Microbe. 2014;16:364-75.

Xiong L, Lee M, Qi M, Yang Y. Identification of defense-related rice genes by suppression subtractive hybridization and differential screening. Mol PlantMicrobe Interact. 2001;14:685-92.

Xue D, Jiang H, Hu J, Zhang X, Guo L, Zeng D, et al. Characterization of physiological response and identification of associated genes under heat stress in rice seedlings. Plant Physiol Biochem. 2012;61:46-53.

Yang F, Li W, Jørgensen HJ. Transcriptional reprogramming of wheat and the hemibiotrophic pathogen Septoria tritici during two phases of the compatible interaction. PLoS One. 2013;8:e81606.

Zhang XN, Qu ZC, Wan YZ, Zhang HW, Shen DL. Application of suppression subtractive hybridization (SSH) to cloning differentially expressed CDNA in Dunaliella salina (chlorophyta) under hyperosmotic shock. Plant Mol Biol Rep. 2002;20:49-57.

Zhou Q, Yu Q, Wang Z, Pan Y, Lv W, Zhu L, et al. Knockdown of GDCH gene reveals reactive oxygen species-induced leaf senescence in rice. Plant Cell Environ. 2013;36:1476-89.

Ready to submit your research? Choose BMC and benefit from:

- fast, convenient online submission

- thorough peer review by experienced researchers in your field

- rapid publication on acceptance

- support for research data, including large and complex data types

- gold Open Access which fosters wider collaboration and increased citations

- maximum visibility for your research: over $100 \mathrm{M}$ website views per year

At $\mathrm{BMC}$, research is always in progress.

Learn more biomedcentral.com/submissions 